\title{
IN VITRO ANTIFUNGAL ACTIVITY OF THREE SAUDI PLANT EXTRACTS AGAINST SOME PHYTOPATHOGENIC FUNGI
}

\author{
Abdul Aziz A. Al-Askar* \\ Biology Department, Teachers College, King Saud University, Riaydh, Saudi Arabia \\ P.O. Box No. 4341, Riyadh 11491
}

Received: August 4, 2012

Accepted: September 17, 2012

\begin{abstract}
The antifungal activities of ethanolic extracts of three Saudi plants; camel thorn (Alhagi maurorum Medic.), caper (Capparis spinosa L.), and pomegranate (Punica granatum L.) were investigated in vitro against Alternaria alternata, Fusarium oxysporum, Phoma destructiva, Rhizoctonia solani, and Sclerotium rolfsii at concentrations of 0,3,6, and 9\% (v/v). All tested plant extracts; seeds, roots, and rinds had different degrees of antifungal activity against the tested fungi. When compared with the control, the highest antifungal activity was recorded for camel thorn seeds extract at a concentration of $9 \%$, while, pomegranate rinds extract at $9 \%$ came in second. Camel thorn rinds extract came in last even when used at a high concentration. The ethanolic extract of camel thorn seeds may be recommended as a potent bio-fungicide. Extensive studies should be undertaken for the ethanolic extract of camel thorn seeds as a strong antifungal agent against fungal plant diseases.
\end{abstract}

Key words: Alternaria alternata, Fusarium oxysporum, Phoma destructiva, Rhizoctonia solani, Sclerotium rolfsii

\section{INTRODUCTION}

Fungal infections cause significant loss in many economic crops. Crop losses are estimated to be about $14 \%$ worldwide (Agrios 2005). Among the phytopathogenic fungi, Alternaria alternata (Fr.) Keissl, Fusarium oxysporum Schlecht., Phoma destructiva Plowr., Rhizoctonia solani Kühn., and Sclerotium rolfsii Sacc. are reported as destructive. They cause leaf spots, Fusarium wilt, Phoma rot, Rhizoctonia root rot, and root and stem-rot on a wide variety of agricultural crops, respectively (Yaqub and Shahzad 2005; Abdel-Fattah et al. 2011; Alwathnani and Perveen 2012).

Chemical control may be available to effectively and extensively reduce the effects of most fungal disease but field application of these chemical fungicides may not always be desirable. Excessive and improper use of these fungicides presents a danger to the health of humans, animals, and the environment. Therefore, an extensive search for biofugicides that are environmentally safe and easily biodegradable have been carried out during the last two decades (Gnanamanickam 2002).

The investigation of plants containing natural antimicrobial metabolites for plant protection has been identified as a desirable method of disease control (Rai and Carpinella 2006). Various plant products like plant extracts, essential oils, gums, resins etc. were shown to exert biological activity in vitro and in vivo and are used as bio-fungicidal compounds (Fawzi et al. 2009; Al-Askar and Rashad 2010). The main reasons for using essential oils as antifungal agents are because they are natural in origin and because there is a low chance of pathogens developing resistance to them. Essential oils may have a minimum adverse effect on the physiological processes of plants and have less environmental hazards compared to their synthetic alternatives. Since essential oils are plant products, they are easily convertible into a common organic material (eco-friendly) (Gnanamanickam 2002).

The aim of this work was to investigate the antifungal activity of ethanolic extracts of camel thorn (Alhagi maurorum Medic.), caper (Capparis spinosa L.), and pomegranate (Punica granatum L.) in vitro, on the growth of the tested fungi (A. alternata, F. oxysporum, P. destructiva, R. solani, and $S$. rolfsii).

\section{MATERIALS AND METHODS}

\section{Plant material and fungi}

Three Saudi plant species (camel thorn, caper, and pomegranate) were collected from the various parts of the Riyadh region in Saudi Arabia. Plants were randomly collected to increase the chance of finding plants with bioactive extracts. The plants were identified by the Herbarium at King Saud University, College of Food and Agricultural Sciences.

The fungal strains A. alternata, F. oxysporum, P. destructiva, R. solani, and S. rolfsii were originally isolated from different naturally diseased plants collected from different agricultural fields in the Riyadh region. All fungi were 
cultured on PDA (Potato Dextrose Agar) (Difco, USA) plates, and incubated at $28^{\circ} \mathrm{C}$ for one week. Purification of the resulting isolates was done using the hyphal tip or single spore techniques to obtain pure cultures. The detected isolates were then transferred into a slant of PDA and kept at $4^{\circ} \mathrm{C}$ for further studies. Pure cultures of the isolated fungi were identified according to the cultural properties, morphological, and microscopical characteristics of each fungus (Domsch et al. 1980; Burgess and Liddell 1983; Watanabe 2002).

\section{In vitro antifungal activity of the plant extracts}

The plant material, seeds, and rinds of camel thorn, caper roots, and pomegranate rinds were washed with distilled water and then dried in the shade. Next, they were finely ground to powder. Fifty grams of each plant material in powder form was homogenized in a laboratory blender in $200 \mathrm{ml}$ of ethanol (96\%) and distilled water $(20: 80 \mathrm{v} / \mathrm{v})$ for $10 \mathrm{~min}$, and then left in dark glass bottles for $72 \mathrm{~h}$ at room temperature for complete extraction. The extracts were filtered through thin cheesecloth sheets. The final extracts were collected separately in other dark glass bottles and exposed to $60^{\circ} \mathrm{C}$ in a water bath for $30 \mathrm{~min}$ for ethanol evaporation. The collected extracts were then stored in a refrigerator at $5^{\circ} \mathrm{C}$ until needed. The plant extracts were added to conical flasks containing sterilized PDA before solidification to obtain the proposed concentrations of $0,3,6$, and $9 \%(\mathrm{v} / \mathrm{v})$. Twenty $\mathrm{ml}$ of amended media were poured into $9 \mathrm{~cm}$ diameter Petri dishes. For each treatment, 3 replicates (plates) were used. All plates were inoculated individually with $0.5 \mathrm{~cm}$ diameter discs of the tested fungal cultures, and then incubated in the dark at $28 \pm 2{ }^{\circ} \mathrm{C}$, the linear growth of each fungus was measured 3, 6 and 9 days after inoculation. All plates were arranged in a complete randomized design.

\section{Statistical Analysis}

All data were subjected to analysis of variance using the statistical analysis software (CoStat 2005). Comparisons among means were made using Duncan's multiple range test (Duncan 1955).

\section{RESULTS}

\section{In vitro antifungal activity of the plant extracts}

The antifungal activities of the plant extracts (seeds and rinds of camel thorn, caper roots, and pomegranate rinds) were investigated against the linear growth of five fungi at different concentrations $(3,6$, and $9 \%)$. Data concerning the growth reduction of $R$. solani in response to the tested plant extracts is presented in table 1 . All tested plant extracts had different degrees of antifungal activity against $R$. solani. Three days after inoculation, it was found that there was an inverse relationship between the concentration of the plant extracts and the linear growth of $R$. solani i.e. as the concentration increases the linear growth decreases. The highest antifungal activity was recorded for camel thorn seed extract at a concentration of $9 \%$ when compared with all other treatments. The linear growth of $R$. solani continued to increase after 6 days of inoculation at different concentrations of the tested plant extracts. At day 9, plates treated with the plant extracts (camel thorn rinds, caper roots, or pomegranate rinds) at 3 and $6 \%$ reached full growth. Camel thorn seeds extract at a $9 \%$ concentration, continued to be the most effective inhibitor of $R$. solani growth, after 9 days of inoculation. Camel thorn rinds extract came in last even when used at high concentrations. Caper roots and pomegranate rind extracts ranked second.

Table 1. Effect of different plant extracts on the linear growth of $R$. solani

\begin{tabular}{|c|c|c|c|c|c|c|c|c|c|c|c|c|c|}
\hline \multirow{3}{*}{ Time } & \multicolumn{13}{|c|}{ Inward linear growth $[\mathrm{cm}]$} \\
\hline & \multirow{2}{*}{$\begin{array}{c}\text { the } \\
\text { control }\end{array}$} & \multicolumn{3}{|c|}{$\begin{array}{c}\text { camel thorn seeds } \\
{[\%]}\end{array}$} & \multicolumn{3}{|c|}{$\begin{array}{l}\text { camel thorn rinds } \\
{[\%]}\end{array}$} & \multicolumn{3}{|c|}{$\begin{array}{c}\text { caper roots } \\
{[\%]} \\
\end{array}$} & \multicolumn{3}{|c|}{$\begin{array}{c}\text { pomegranate rinds } \\
{[\%]}\end{array}$} \\
\hline & & 3 & 6 & 9 & 3 & 6 & 9 & 3 & 6 & 9 & 3 & 6 & 9 \\
\hline 3 days & $9.0 \mathrm{a}^{* *}$ & $3.9 \mathrm{~h}$ & $2.1 \mathrm{j}$ & $1.1 \mathrm{k}$ & $9.0 \mathrm{a}$ & $7.0 \mathrm{~b}$ & $6.8 \mathrm{c}$ & $5.4 \mathrm{e}$ & $4.4 \mathrm{~g}$ & $2.9 \mathrm{i}$ & $6.4 \mathrm{~d}$ & $4.4 \mathrm{~g}$ & $3.0 \mathrm{i}$ \\
\hline 6 days & $9.0 \mathrm{a}$ & $4.4 \mathrm{e}$ & $2.4 \mathrm{f}$ & $1.1 \mathrm{~g}$ & $9.0 \mathrm{a}$ & $9.0 \mathrm{a}$ & $9.0 \mathrm{a}$ & $8.8 \mathrm{~b}$ & $8.0 \mathrm{c}$ & $4.4 \mathrm{e}$ & $9.0 \mathrm{a}$ & $9.0 \mathrm{a}$ & $5.4 \mathrm{~d}$ \\
\hline 9 days & $9.0 \mathrm{a}$ & $4.9 \mathrm{~d}$ & $2.4 \mathrm{e}$ & $1.1 \mathrm{f}$ & $9.0 \mathrm{a}$ & $9.0 \mathrm{a}$ & $9.0 \mathrm{a}$ & $9.0 \mathrm{a}$ & $9.0 \mathrm{a}$ & $5.2 \mathrm{c}$ & $9.0 \mathrm{a}$ & $9.0 \mathrm{a}$ & $6.9 \mathrm{~b}$ \\
\hline
\end{tabular}

* each value represents the mean of 3 replicates

**values within a row followed by the same letter are not significantly different according to Duncan's multiple range test ( $\mathrm{p} \leq 0.05$ )

Table 2. Effect of different plant extracts on the linear growth of F. oxysporum

\begin{tabular}{|c|c|c|c|c|c|c|c|c|c|c|c|c|c|}
\hline \multirow{3}{*}{ Time } & \multicolumn{13}{|c|}{ Inward linear growth ${ }^{*}[\mathrm{~cm}]$} \\
\hline & \multirow{2}{*}{$\begin{array}{l}\text { the } \\
\text { control }\end{array}$} & \multicolumn{3}{|c|}{$\begin{array}{c}\text { camel thorn seeds } \\
{[\%]}\end{array}$} & \multicolumn{3}{|c|}{$\begin{array}{c}\text { camel thorn rinds } \\
{[\%]}\end{array}$} & \multicolumn{3}{|c|}{$\begin{array}{c}\text { caper roots } \\
{[\%]}\end{array}$} & \multicolumn{3}{|c|}{$\begin{array}{c}\text { pomegranate rinds } \\
{[\%]}\end{array}$} \\
\hline & & 3 & 6 & 9 & 3 & 6 & 9 & 3 & 6 & 9 & 3 & 6 & 9 \\
\hline 3 days & $3.1 \mathrm{a}^{* *}$ & $2.0 \mathrm{~g}$ & $2.0 \mathrm{~g}$ & $1.8 \mathrm{~h}$ & $2.6 \mathrm{c}$ & $2.7 \mathrm{bc}$ & $2.8 \mathrm{~b}$ & $2.5 \mathrm{~d}$ & $2.4 \mathrm{de}$ & 2.3 ef & $2.2 \mathrm{f}$ & $1.8 \mathrm{~h}$ & $1.4 \mathrm{i}$ \\
\hline 6 days & $7.7 \mathrm{a}$ & $2.9 \mathrm{~g}$ & $2.5 \mathrm{~h}$ & $2.1 \mathrm{i}$ & $4.6 \mathrm{de}$ & $5.1 \mathrm{c}$ & $5.9 \mathrm{~b}$ & $5.2 \mathrm{c}$ & $4.8 \mathrm{~d}$ & $4.5 \mathrm{e}$ & $4.5 \mathrm{e}$ & $3.3 \mathrm{f}$ & $2.5 \mathrm{~h}$ \\
\hline 9 days & $9.0 \mathrm{a}$ & $3.8 \mathrm{~h}$ & $3.2 \mathrm{i}$ & $2.5 \mathrm{j}$ & $6.6 \mathrm{f}$ & $7.6 \mathrm{~d}$ & $8.3 \mathrm{~b}$ & $8.0 \mathrm{c}$ & $7.2 \mathrm{e}$ & $6.6 \mathrm{f}$ & $6.8 \mathrm{f}$ & $5.0 \mathrm{~g}$ & $3.7 \mathrm{~h}$ \\
\hline
\end{tabular}

*each value represents the mean of 3 replicates

**values within a row followed by the same letter(s) are not significantly different according to Duncan's multiple range test ( $\mathrm{p} \leq 0.05$ ) 
Table 3. Effect of different plant extracts on the linear growth of S. rolfsii

\begin{tabular}{|c|c|c|c|c|c|c|c|c|c|c|c|c|c|}
\hline \multirow{3}{*}{ Time } & \multicolumn{13}{|c|}{ Inward linear growth* $[\mathrm{cm}]$} \\
\hline & \multirow{2}{*}{$\begin{array}{l}\text { the } \\
\text { control }\end{array}$} & \multicolumn{3}{|c|}{$\begin{array}{c}\text { camel thorn seeds } \\
{[\%]}\end{array}$} & \multicolumn{3}{|c|}{$\begin{array}{c}\text { camel thorn rinds } \\
{[\%]}\end{array}$} & \multicolumn{3}{|c|}{$\begin{array}{c}\text { caper roots } \\
{[\%]}\end{array}$} & \multicolumn{3}{|c|}{$\begin{array}{c}\text { pomegranate rinds } \\
{[\%]}\end{array}$} \\
\hline & & 3 & 6 & 9 & 3 & 6 & 9 & 3 & 6 & 9 & 3 & 6 & 9 \\
\hline 3 days & $2.1 \mathrm{a}^{* *}$ & $1.7 \mathrm{~b}$ & $1.0 \mathrm{e}$ & $0.8 \mathrm{f}$ & $1.6 \mathrm{~b}$ & $2.0 \mathrm{a}$ & $2.0 \mathrm{a}$ & $1.5 \mathrm{c}$ & $1.5 \mathrm{c}$ & $1.3 \mathrm{~d}$ & $1.7 \mathrm{~b}$ & $1.5 \mathrm{c}$ & $1.4 \mathrm{~cd}$ \\
\hline 6 days & $4.0 \mathrm{a}$ & $1.4 \mathrm{~g}$ & $1.2 \mathrm{~h}$ & $0.8 \mathrm{i}$ & $2.4 \mathrm{de}$ & $4.0 \mathrm{a}$ & $4.0 \mathrm{a}$ & $2.7 \mathrm{c}$ & $2.5 \mathrm{~d}$ & $2.4 \mathrm{e}$ & $2.8 \mathrm{~b}$ & $2.3 \mathrm{e}$ & $2.2 \mathrm{f}$ \\
\hline 9 days & $6.1 \mathrm{a}$ & $1.5 \mathrm{f}$ & $1.4 \mathrm{f}$ & $0.9 \mathrm{~g}$ & $3.2 \mathrm{e}$ & $5.7 \mathrm{~b}$ & $5.8 \mathrm{~b}$ & $3.9 \mathrm{c}$ & $3.6 \mathrm{~d}$ & $3.3 \mathrm{e}$ & $3.8 \mathrm{~d}$ & $3.2 \mathrm{e}$ & $3.3 \mathrm{e}$ \\
\hline
\end{tabular}

*each value represents the mean of 3 replicates

**values within a row followed by the same letter are not significantly different according to Duncan's multiple range test $(p \leq 0.05)$

Table 4. Effect of different plant extracts on the linear growth of A. alternata

\begin{tabular}{|c|c|c|c|c|c|c|c|c|c|c|c|c|c|}
\hline \multirow{3}{*}{ Time } & \multicolumn{13}{|c|}{ Inward linear growth ${ }^{*}[\mathrm{~cm}]$} \\
\hline & \multirow{2}{*}{$\begin{array}{l}\text { the } \\
\text { control }\end{array}$} & \multicolumn{3}{|c|}{$\begin{array}{c}\text { camel thorn seeds } \\
{[\%]}\end{array}$} & \multicolumn{3}{|c|}{$\begin{array}{c}\text { camel thorn rinds } \\
{[\%]}\end{array}$} & \multicolumn{3}{|c|}{$\begin{array}{c}\text { caper roots } \\
{[\%]}\end{array}$} & \multicolumn{3}{|c|}{$\begin{array}{c}\text { pomegranate rinds } \\
{[\%]}\end{array}$} \\
\hline & & 3 & 6 & 9 & 3 & 6 & 9 & 3 & 6 & 9 & 3 & 6 & 9 \\
\hline 3 days & $2.9 \mathrm{a}^{* *}$ & $1.7 \mathrm{~d}$ & $1.5 \mathrm{e}$ & $0.8 \mathrm{f}$ & $2.6 \mathrm{~b}$ & $2.8 \mathrm{a}$ & $2.9 \mathrm{a}$ & $2.2 \mathrm{~d}$ & $1.7 \mathrm{~d}$ & $1.5 \mathrm{e}$ & $2.2 \mathrm{c}$ & $1.6 \mathrm{e}$ & $1.5 \mathrm{e}$ \\
\hline 6 days & $6.9 \mathrm{a}$ & $2.3 \mathrm{i}$ & $2.0 \mathrm{j}$ & $1.1 \mathrm{k}$ & $5.2 \mathrm{c}$ & $6.7 \mathrm{~b}$ & $6.7 \mathrm{~b}$ & $3.5 \mathrm{e}$ & $3.3 \mathrm{f}$ & $2.8 \mathrm{~g}$ & $4.9 \mathrm{~d}$ & $3.6 \mathrm{e}$ & $2.7 \mathrm{~h}$ \\
\hline 9 days & $9.0 \mathrm{a}$ & $2.8 \mathrm{i}$ & $2.5 \mathrm{j}$ & $1.3 \mathrm{k}$ & $7.1 \mathrm{c}$ & $9.0 \mathrm{a}$ & $9.0 \mathrm{a}$ & $5.1 \mathrm{e}$ & $4.6 \mathrm{f}$ & $4.1 \mathrm{~h}$ & $7.4 \mathrm{~b}$ & $5.3 \mathrm{~d}$ & $4.4 \mathrm{~g}$ \\
\hline
\end{tabular}

*each value represents the mean of 3 replicates

${ }^{* *}$ values within a row followed by the same letter are not significantly different according to Duncan's multiple range test $(\mathrm{p} \leq 0.05)$

Table 5. Effect of different plant extracts on the linear growth of $P$. destructiva

\begin{tabular}{|c|c|c|c|c|c|c|c|c|c|c|c|c|c|}
\hline \multirow{3}{*}{ Time } & \multicolumn{13}{|c|}{ Inward linear growth* $[\mathrm{cm}]$} \\
\hline & \multirow{2}{*}{$\begin{array}{l}\text { the } \\
\text { control }\end{array}$} & \multicolumn{3}{|c|}{$\begin{array}{c}\text { camel thorn seeds } \\
{[\%]}\end{array}$} & \multicolumn{3}{|c|}{$\begin{array}{c}\text { camel thorn rinds } \\
{[\%]}\end{array}$} & \multicolumn{3}{|c|}{$\begin{array}{c}\text { caper roots } \\
{[\%]}\end{array}$} & \multicolumn{3}{|c|}{$\begin{array}{c}\text { pomegranate rinds } \\
{[\%]}\end{array}$} \\
\hline & & 3 & 6 & 9 & 3 & 6 & 9 & 3 & 6 & 9 & 3 & 6 & 9 \\
\hline 3 days & $9.0 \mathrm{a}^{* *}$ & $6.9 \mathrm{c}$ & $5.1 \mathrm{~d}$ & $1.8 \mathrm{e}$ & $9.0 \mathrm{a}$ & $9.0 \mathrm{a}$ & $9.0 \mathrm{a}$ & $9.0 \mathrm{a}$ & $9.0 \mathrm{a}$ & $9.0 \mathrm{a}$ & $9.0 \mathrm{a}$ & $9.0 \mathrm{a}$ & $7.2 \mathrm{~b}$ \\
\hline 6 days & $9.0 \mathrm{a}$ & $6.9 \mathrm{~b}$ & $4.9 \mathrm{c}$ & $1.7 \mathrm{~d}$ & $9.0 \mathrm{a}$ & $9.0 \mathrm{a}$ & $9.0 \mathrm{a}$ & $9.0 \mathrm{a}$ & $9.0 \mathrm{a}$ & $9.0 \mathrm{a}$ & $9.0 \mathrm{a}$ & $9.0 \mathrm{a}$ & $9.0 \mathrm{a}$ \\
\hline 9 days & $9.0 \mathrm{a}$ & $7.2 \mathrm{~b}$ & $5.1 \mathrm{c}$ & $1.7 \mathrm{~d}$ & $9.0 \mathrm{a}$ & $9.0 \mathrm{a}$ & $9.0 \mathrm{a}$ & $9.0 \mathrm{a}$ & $9.0 \mathrm{a}$ & $9.0 \mathrm{a}$ & $9.0 \mathrm{a}$ & $9.0 \mathrm{a}$ & $9.0 \mathrm{a}$ \\
\hline
\end{tabular}

*each value represents the mean of 3 replicates

${ }^{* *}$ values within a row followed by the same letter are not significantly different according to Duncan's multiple range test ( $\mathrm{p} \leq 0.05$ )

Results presented in table 2 show the effects of the tested plant extracts on the linear growth of F. oxysporum. At day 3, plant extracts of camel thorn seeds, caper roots or pomegranate rinds significantly reduced the linear growth of F. oxysporum at different degrees, with the increase of the concentrations. At the same time, it was found that camel thorn rinds extract significantly reduced the linear growth of F. oxysporum but the inhibitory effect significantly decreased with the increase in the concentration. The linear growth of F. oxysporum continued to increase after 6 days of inoculation at different concentrations of the tested plant extracts. At day 9, camel thorn seeds extract at a $9 \%$ concentration, continued to be the most effective inhibitor of the growth of F. oxysporum compared with the control, while, pomegranate rinds extract came in second.

At day 3, it was observed that the inhibitory effect of the plant extracts against $S$. rolfsii significantly increased with the increase in the concentration. Camel thorn rinds extract (Table 3) however, did not increase but the same observation with F. oxysporum was recorded. The linear growth of $S$. rolfsii continued to increase after 6 days of inoculation at different concentrations of the tested plant extracts. The highest antifungal activity was recorded for camel thorn seed extract at a concentration of $9 \%$ when compared with the control after 9 days of inoculation.

In vitro antifungal activities of the plant extracts against $A$. alternata are presented in table 4 . At day 3 , it was observed that plant extracts of camel thorn seeds, caper roots or pomegranate rinds significantly reduced the linear growth of A. alternata with the increase in the concentrations. In contrast, there was no additional inhibitory effect with the increase of the plant extract from camel thorn rinds. The linear growth of A. alternata continued to increase after 6 days of inoculation with different concentrations of the tested plant extracts. At day 9, the highest antifungal activity was recorded for camel thorn seed extract at a concentration of $9 \%$ when compared with the control. On the other hand, camel thorn rinds extract, even at high concentrations, came in last.

The effect of different plant extracts on the linear growth of $P$. destructiva is presented in table 5. At day 9, no significant differences were recorded in the linear growth of $P$. destructiva when treated with the plant extracts of camel thorn rinds, caper roots or pomegranate. In contrast, camel thorn seeds extract significantly decreased 
the linear growth of $P$. destructiva with the increase in its concentration when compared with the control even after 9 days of inoculation.

\section{DISCUSSION}

The geographical location of Saudi Arabia has provided an ideal environment for the growth and nourishment of different medicinal plant species including camel thorn, caper, and pomegranate. The country is gifted with diverse vegetation types occurring in the desert, semidesert, and mountainous ecosystems (Ahmad and Ghazanfar 1991).

The antifungal activities of the tested plant extracts (camel thorn, caper, and pomegranate) were investigated at different concentrations. Our results indicated that all tested plant extracts had different degrees of antifungal activity against the tested fungi. The in vitro efficacy of pomegranate, caper, and camel thorn against different pathogens has been investigated by various researchers (Lam et al. 2009; Dahham et al. 2010; Abd-Ellatif et al. 2011). The antifungal activity attained by these plant extracts is attributed to their chemical composition. Based on spectral analyses, the compound from the pomegranate rinds extract that exhibited strong antifungal activity was previously identified as punicalagin. Punicalagin showed strong activity against Candida spp. (Endo et al. 2010). Moreover, it has antibacterial, antioxidant, anticancer, and anti-inflammatory properties (Miguel et al. 2010). Previous chemical studies have reported that alkaloids, lipids, polyphenols, flavonoids, indole, and glucosinolates were isolated from caper extract (Tlili et al. 2010). The richness of the caper plant with the total phenolic compounds, rutin, tocopherols, carotenoids, and vitamin C could be the main factor in its antimicrobial effects (Mahboubi et al. 2012).

Our results revealed that the highest antifungal activity was recorded for camel thorn seeds extract at a concentration of $9 \%$ when compared with the control. The obtained result is in accordance with that achieved by Abd-Ellatif et al. (2011) on Aspergillus flavus, A. alternata, F. oxysporum, F. solani, Bipolaris oryzae, Chetomium sp. and Mucor sp. In another study, the ethanolic extract of the camel thorn plant showed significant antimicrobial activity against Gram negative, Gram positive bacteria as well as unicellular and filamentous fungi (Zain et al. 2012). Furthermore, it has some medicinal properties such as antioxidant, anti-inflammatory (Awaad et al. 2011), antiulcerogenic (Awaad et al. 2006) and antidiarrhoeal activity (Gutierrez et al. 2007). Phytochemical screening of camel thorn extract revealed the presence of flavonoids, glycosides, alkaloids, saponins, tannins, steroids, and anthraquinone as major constituents (Abdel Rahman et al. 2011). The additional constituents were reported in the camel thorn extract: $\beta$-sitosterol, cinnamic acid, coumaric acid, and hydroxybenzoic acid (Ahmad et al. 2009). The activity of camel thorn plants could be explained, at least by their antimicrobial properties, due to their high flavonoid contents.

The results of this study support the traditional usage of the studied plants. Hence, the objective of this study was to determine if plant extracts could provide antifungal activity against some phytopathogenic fungi. Considering their attribute and broad-spectrum activities, successful development of such antifungal compounds would not only provide a potent tool for control of the tested pathogenic fungi, but also could promise success in multipurpose biorational alternatives to conventional fungicides, for the management of other plant diseases. Extensive studies should be undertaken about the ethanolic extract of camel thorn seeds as a strong antifungal agent against fungal plant diseases.

\section{ACKNOWLEDGEMENT}

The author extends his appreciation to the Research Center of Teachers College, King Saud University for funding this work through project No. RSP-TCR-14.

\section{REFERENCES}

Abdel-Fattah G.M., El-Haddad S.A., Hafez E.E., Rashad Y.M. 2011. Induction of defense responses in common bean plants by arbuscular mycorrhizal fungi. Microbiol. Res. 166 (4): 268-281.

Abd-Ellatif S., Abdel Rahman S.M., Deraz S.F. 2011. Promising antifungal effect of some folkloric medicinal plants collected from El- Hammam habitat, Egypt against dangerous pathogenic and toxinogenic fungi. ARPN J. Agric. Biol. Sci. 6 (9): 25-32.

Abdel Rahman S.M., Abd-Ellatif S.A., Deraz S.F., Khalil A.A. 2011. Antibacterial activity of some wild medicinal plants collected from western Mediterranean coast, Egypt: Natural alternatives for infectious disease treatment. Afr. J. Biotechnol. 10 (52): 10733-10743.

Agrios G.M. 2005. Plant Pathology. 5th ed. AP, New York, NY, $922 \mathrm{pp}$.

Ahmad H.A., Ghazanfar S.A. 1991. Conservation of medicinal plants on the Arabian Peninsula. Two case studies: Med. Plant Conserv. 3 (1): 15-16.

Ahmad S., Ahmad I., Saleem M., Abdul-Jabbar A., Rehman I., Hassan S., Akhtar K.S., Choudhary M.I. 2009. Secondary metabolites from Alhagi maurorum. J. Chem. Soc. Pak. 31 (6): 960-963.

Al-Askar A.A., Rashad Y.M. 2010. Efficacy of some plant extracts against Rhizoctonia solani on pea. J. Plant Prot. Res. 50 (3): 239-243.

Alwathnani H.A., Perveen K. 2012. Biological control of fusarium wilt of tomato by antagonist fungi and cyanobacteria. Afr. J. Biotechnol. 11 (5): 1100-1105.

Awaad A.S., El-Meligy R.M., Qenawy S.A., Atta A.H., Soliman G.A. 2011. Anti-inflammatory, antinociceptive and antipyretic effects of some desert plants. J Saudi Chem. Soc. 15 (4): 367-373.

Awaad A.S., Maitland D.J., Soliman G.A. 2006. Antiulcerogenic activity of Alhagi maurorum. Pharmac. Biol. 44 (4): 292-296.

Burgess L.W., Liddell C.M. 1983. Laboratory Manual for Fusarium Research. Fusarium Research Laboratory, Department of Plant Pathology and Agricultural Entomology. The University of Sydney, Australia, 133 pp.

CoStat. 2005. Cohort Software, 798 Lighthouse Ave. PMB 320 Monterey, USA, 65 pp. 
Dahham S.S., Ali M.N., Tabassum H., Khan M. 2010. Studies on antibacterial and antifungal activity of pomegranate ( $p u-$ nica granatum 1.). Am. Eurasian J. Agric. Environ. Sci. 9 (3): 273-281.

Domsch K.H., Gams W., Anderson T.H. 1980. Compendium of Soil Fungi. Vols. 1, 2. AP, New York, 640 pp.

Duncan D.B. 1955. Multiple range and multiple F test. Biometrics 11 (1): 1-24.

Endo E.H., Cortez D.A., Ueda-Nakamura T., Nakamura C.V., Dias Filho B.P. 2010. Potent antifungal activity of extracts and pure compound isolated from pomegranate peels and synergism with fluconazole against Candida albicans. Res. Microbiol. 161 (7): 534-540.

Fawzi E.M., Khalil A.A., Afifi A.F. 2009. Antifungal effect of some plant extracts on Alternaria alternata and Fusarium oxysporum. Afr. J. Biotechnol. 8 (11): 2590-2597.

Gnanamanickam S.S. 2002. Biological Control of Crop Diseases. New York. Basel: Marcel Dekker, Inc., 15 pp.

Gutierrez S.P., Sanchez M.A.Z., Gonzalez C.P., Garcia L.A. 2007. Antidiarrhoeal activity of different plants used in traditional medicine. Afr. J. Biotech. 6 (25): 2988-2994.

Lam S.K., Han Q.F., Ng T.B. 2009. Isolation and characterization of a lectin with potentially exploitable activities from caper (Capparis spinosa) seeds. Biosci. Rep. 29 (5): 293-299.
Mahboubi A., Kamalinejad M., Shalviri M., Karbasi Z., Jafariazar Z., Asgharian R. 2012. Evaluation of antibacterial activity of three Iranian medicinal plants. Afr. J. Microbiol. Res. 6 (9): 2048-2052.

Miguel M.G., Neves M.A., Antunes M.D. 2010. Pomegranate (Punica granatum L.): a medicinal plant with myriad biological properties - a short review. J. Medic. Plants Res. 4 (25): 2836-2847.

Rai M., Carpinella M. 2006. Naturally Occurring Bioactive Compounds. Elsevier, Amsterdam, p. 502.

Tlili N., Khaldi A., Triki S., Munne-Bosch S. 2010. Phenolic compounds and vitamin antioxidants of caper (Capparis spinosa). J. Plant Foods Hum. Nutr. 65 (3): 260-265.

Watanabe T. 2002. Pictorial Atlas of Soil and Seed Fungi: Morphologies of Cultured Fungi and Key to Species. 2nd ed. CRC Press, Boca Raton, Florida, USA, 504 pp.

Yaqub F., Shahzad S. 2005. Pathogenicity of Sclerotium rolfsii on different crops and effect of inoculum density on colonization of mungbean and sunflower. Pak. J. Bot. 37 (1): 175-180.

Zain M.E., Awaad A.S., Al-Outhman M.R., El-Meligy R.M. 2012. Antimicrobial activities of Saudi Arabian desert plants. Phytopharmacology 2 (1): 106-113 